\title{
MORF AMALGAM DALAM BAHASA INDONESIA
}

\author{
Oleh: Joko Santoso
}

\begin{abstract}
Abstrak
Tulisan ini merupakan pengantar dalam memahami pengertian dasar morf amalgam, morf amalgam dalam bahasa Indonesia, dan kesamaan atau kemiripan gejala yang dialaminya dengan gejala homonimi dan polisemi. Berdasarkan teori yang ada, khususnya teori morfologi yang berkembang akhir-akhir ini, gejala amalgamisasi morfemis dalam bahasa Indonesia diupayakan untuk diidentifikasi dan dideskripsikan.

Berdasarkan hasil kajian yang telah dilakukan dapat disimpulkan bahwa relasi antara morf dan morfem sebagai wujud dan yang diwujudkan menampakkan tiga kemungkinan: (I) satu morf merealisasikan satu morfem, (2) dua morf atau lebih merealisasikan satu morfem, dan (3) satu morf merealisasikan dua morfem atau lebih. Morf yang merealisasikan lebih dari satu morfem disebut morf amalgam. Morf amalgam dalam bahasa Indonesia dapat berupa afiks atau leksem. Di samping itu, gejala yang terjadi pada morf amalgam berbeda dengan gejala homonimi dan polisemi.
\end{abstract}

\section{A. Pendahuluan}

Pada umumnya di dalam buku-buku morfologi — juga di dalam buku morfologi bahasa Indonesia - terdapat seksi khusus yang membahas morf dan morfem. Di dalam seksi itu dibicarakan hakikat (pengertian), wujud, dan alternasi morfem, serta beberapa prinsip penentuannya. Morfem biasanya dibatasi sebagai "an abstract unit realised by morphs; the smallest grammatical unit of language or the smallest meaning-bearing unit of language (Bauer 1988:247; Matthews 1974:83). Sesuai dengan batasan itu, morfem dibatasi sebagai: (1) unit bahasa yang bersifat abstrak, (2) unit gramatikal terkecil, atau (3) unit bermakna terkecil (lihat pula, Robins 1992:249). Sebagai unit yang bersifat abstrak, dalam pemakaian bahasa sehari-hari, morfem direalisasikan oleh morf. Bauer (1988:247) menyatakan juga bahwa morf adalah "a constituent element of a word-form". Sebagai realisasi atau perwujudan morfem, morf adalah elemen yang merupakan

\footnotetext{
- Dosen Jurusan Pendidikan Bahasa dan Sastra Indonesia FPBS IKIP Yogyakarta
} 
konstituen suatu bentuk-kata. Sebagai wujud morfem, morf berupa fonem atau urutan fonem yang berasosiasi dengan suatu makna (Kridalaksana 1993: 141).

Sebagai unit abstrak, unit gramatikal terkecil, atau sebagai unit bermakna terkecil, morfem dapat diwujudkan oleh satu atau beberapa morf. Kata bunga, daun, dahan, akar, batang, buah adalah kata-kata monomorfemis. Sebagai kata bermorfem tunggal, kata-kata itu tentu saja (masing-masing) hanya diwujudkan oleh sebuah morf. Di dalam kata berbunga, berdaun, berdahan, berakar, berbatang, dan berbuah terdapat morfem \{ber-\} dan beberapa morfem dasar. Morfem \{ber- $\}$ tersebut, di dalam masing-masing kata itu memiliki makna dan diwujudkan oleh morf yang sama, yaitu /ber-/. Dengan kata lain, terdapat satu morfem $\{$ ber- $\}$ yang direalisasikan oleh satu morf. Berbeda halnya dengan itu, di dalam kata menyabit, memaku, menggunting, dan menatah terdapat satu morfem $\{\operatorname{me}(\mathbb{N})-\}$ (atau ditandai dengan sebutan lain apa pun) yang berarti 'menggunakan' yang diwujudkan oleh morf $/$ meñ- $/$, /mem- $/$, /men- $/$, dan /men-/ yang memiliki bentuk fonetis berbeda-beda. Oleh ahli morfologi, dijelaskan bahwa perbedaan wujud morf itu disebabkan oleh kondisi fonologis lingkungan tempat morf-morf itu berada. Realisasi segmen bunyi yang berbeda pada suatu morf disebabkan oleh persesuaian fonetis dengan segmen bunyi yang berdampingan dengannya. Oleh karena itu, realisasi bunyi nasal $(\mathrm{N})$ pada morfem $\{\operatorname{me}(\mathrm{N})-\}$ di atas bersesuaian dengan segmen bunyi awal morfem dasar yang dilekatinya.

Satu hal yang perlu meńjadi catatan di sini ialah bahwa persesuaian fonologis tersebut tidak ditentukan oleh hakikat morfem atau berkorelasi dengan persesuaian makna. Sebagai morfem yang sama atau berbeda, kaidah persesuaian fonologis seperti di atas tetap berlaku. Oleh karena itu, morfem \{me(N)- $\}$ yang berarti 'menjadi' pada kata menduda menupakan morfem yang berbeda dengan morfem $\{\mathrm{me}(\mathrm{N})-\}$ yang berarti 'menuju' pada kata mendarat, walaupun kedua morfem itu memiliki perwujudan fonologis yang sama, yaitu morf /men- $/$. Sebaliknya, merupakan morfem yang sama dengan morfem $\{\mathrm{me}(\mathrm{N})-\}$ 'menjadi' pada kata menjanda, walaupun memiliki morf yang berbeda, yaitu /meñ-/. Sekali lagi dapat dikatakan bahwa perbedaan atau persamaan wujud morfem tidak ditentukan oleh hakikat atau status morfem sebagai unit abstrak tetapi ditentukan oleh kondisi fonologis yang dilekatinya. 
Bagi ahli bahasa, khususnya bagi ahli morfologi, adanya morf-morf yang berbeda yang merupakan perwujudan morfem yang sama seperti telah dikemukakan di atas (dan beberapa gejala yang berbeda yang berlaku dalam bahasa-bahasa di dunia) tidak lagi menjadi permasalahan yang rumit untuk dijelaskan. Perbedaan wujud morfem seperti itu dapat terjadi dalam bahasabahasa di. dunia oleh karena kondisi fonologis, leksikal, atau gramatikal (Bauer 1988:7-11). Namun, permasalahan ini tampaknya tidak layak untuk dipanjanglebarkan pada kesempatan ini.

Di samping apa yang sudah dikemukakan di atas, di dalam bahasabahasa - juga di dalam bahasa Indonesia - ada satu gejala yang kurang begitu banyak mendapat perhatian ahli morfologi (setidak-tidaknya, fenomena ini tidak dibahas dalam seksi khusus secara panjang lebar). Gejala itu ialah adanya morf yang berasosiasi dengan lebih dari satu ciri makna; atau juga disebut sebagai morf yang merealisasikan lebih dari satu morfem. Morf semacam itu disebut sebagai morf amalgam (Bauer 1988: 20-21).

Di dalam bahasa-bahasa sudah sangat lazim dikenal adanya gejala homonimi dan polisemi. Walaupun demikian, lazimnya, gejala hominimi dan kepolisemian itu berkenaan dengan tataran kata atau leksikal. Homonimi berkenaan dengan dua kata atau lebih yang memiliki ciri bentuk yang sama namun memiliki ciri makna yang berbeda, sedangkan polisemi yaitu pemakaian suatu kata (mungkin juga frase) yang berkorelasi dengan sejumlah (atau lebih dari satu) ciri makna. Kepolisemian yang berkenaan dengan tataran morfem tampaknya tidak pernah dibicarakan dalam bukubuku morfologi atau di dalam buku-buku semantik yang ada; setidaktidaknya dalam publikasi linguistik Indonesia.

Pengertian morf amalgam, morf-morf amalgam dalam bahasa Indonesia, dan kesamaan atau kemiripan gejala yang dialami oleh morf amalgam dengan gejala homonimi dan polisemi akan dicoba untuk dibicarakan dalam tulisan ini.

\section{B. Pengertian Morf Amalgam}

Pada bagian pendahuluan di atas telah dikemukakan bahwa morfem biasanya dibatasi sebagai "an abstract unit realised by morphs; the smallest grammatical unit of language or the smallest meaning-bearing unit of language (Bauer 1988:247; Matthews 1974:83). Sesuai dengan batasan itu, morfem dibatasi sebagai: (1) unit bahasa yang bersifat abstrak, (2) unit 
gramatikal terkecil, atau (3) unit bermakna terkecil. Sebagai unit yang bersifat abstrak, dalam pemakaian bahasa sehari-hari, morfem direalisasikan oleh morf. Bauer (1988:247) menyatakan juga bahwa morf adalah " $a$ constituent element of a word-form". Sebagai realisasi atau perwujudan morfem, morf adalah elemen yang merupakan konstituen suatu bentuk-kata. Dengan demikian, sebagai wujud morfem, morf berupa fonem atau urutan fonem yang berasosiasi dengan suatu makna (Kridalaksana 1993:141; 1989:183).

Sebagai wujud morfem, sebuah morf dapat berasosiasi dengan satu makna atau lebih. Dengan kata lain, sebuah morf dapat berasosiasi dengan sebuah morfem atau lebih. Morf yang berasosiasi dengan dua makna atau lebih, atau mewujudkan dua morfem atau lebih, disebut morf amalgam (Bauer 1988:17; Kridalaksana 1993:11). Dalam hal ini, Bauer menyatakan bahwa "a morph which realises more than one morpheme in this way is called a portmanteau morph". Lebih lanjut, ia menyatakan bahwa "Portmanteau morphs are very common as suffixes in highly inflecting languages". Ia mengilustrasikan sufiks bahasa-bahasa Indo-Eropa yang digunakan sebagai pemarkah kasus dan sekaligus sebagai pemarkah jumlah. Dalam hal ini, ia mengemukakan contoh nomina annus 'tahun' dari bahasa Latin seperti dikutip berikut ini (Bauer 1988:20-21).

$\begin{array}{lll} & \text { tunggal } & \text { jamak } \\ \text { nominatif } & \text { ann.us } & \text { ann.i: } \\ \text { vokatif } & \text { ann.e } & \text { ann.i: } \\ \text { akusatif } & \text { ann.um } & \text { ann.o:s } \\ \text { genitif } & \text { ann.i: } & \text { ann.o:rum } \\ \text { datif } & \text { ann.o: } & \text { ann.i:s } \\ \text { ablatif } & \text { ann.o: } & \text { ann.i:s }\end{array}$

Berdasarkan contoh di atas diketahui bahwa sufiks /-us/ di samping sebagai pemarkah kasus nominatif juga menjadi pemarkah ketunggalan karena kasus nominatif yang bersifat jamak ditandai oleh sufiks /-i:/. Demikian pula sufiks-sufiks yang lain, di samping menandai kasus tertentu juga menandai jumlah; tunggal atau jamak. Di dalam bahasa Inggris, bentuk was adalah morf yang merealisasikan tidak hanya morfem $\{B E\}$ melainkan 
juga morfem \{tunggal\} dan \{past tense\}. Bentuk their pun menampakkan fitur \{orang ketiga\}, \{jamak\}, dan \{milik\}.

Di samping berkenaan dengan sejumlah imbuhan, amalgamisasi juga berkenaan dengan bentuk-bentuk paduan (blend). Bauer (1988:238) menyatakan bahwa

a blend is a new lexeme formed from parts of two or more other lexemes. There is no requirement that the blend should be made up of meaningful parts of the original lexemes, and the original lexemes are frequently unrecognisable in the blend. Examples are stagflation from stagnation and inflantion, smog from smoke and fog and tritical from trite and critical. Blends are also called portmanteau words.

Paduan atau blend adalah leksem baru yang dibentuk dari bagian dua leksem atau lebih. Bagian-bagian yang dipadukan yang diambil dari leksem-leksem itu tidak dapat lagi dikenali maknanya; atau sebaliknya, makna leksem aslinya tidak dapat dikenali lagi melalui bagian-bagian yang digunakan dalam bentuk blend. Makna yang dimiliki bentuk stagflation, tidak dapat dikenali lewat bentuk stag atau flation; makna yang dimiliki bentuk smog tidak dapat dikenali melalui bentuk $s m$ dan og; dan makna yang dimiliki bentuk tritical tidak dapat dikenali pada bentuk tri dan tical. Dengan demikian, leksem baru stagflation, smog, dan tritical adalah bentuk-bentuk monomorfemis; atau bentuk-bentuk satu morf, yang memiliki dua makna. Oleh karena itu, bentuk blend juga disebut bentuk amalgam dan sebagai morf bentuk blend itu juga termasuk morf amalgam.

\section{Keamalgaman Morfemis dalam Bahasa Indonesia}

Dengan berdasar pada pengertian morf dan morfem tersebut di atas, serta secara khusus berdasar pada pengertian morf amalgam, akan dicoba diidentifikasikan adanya morf-morf dalam bahasa Indonesia yang memiliki kecenderungan dapat diklasifikasikan sebagai morf amalgam. Pertamatama akan dibicarakan morf-morf yang berupa afiks dan kemudian morfmorf yang berupa leksem atau bentuk dasar.

Bahasa Indonesia memiliki akhiran $/-i /$ yang bermakna 'lokatif seperti pada verba menggambari, yang bermakna 'frekuentatif' seperti pada verba mencubiti, dan yang bermakna 'objektif' seperti pada verba memerahi. 
Ketiga kata yang memiliki akhiran /-i/d dengan pengertiannya masing-masing tersebut dapat dilihat dengan lebih jelas pada perbandingan antara kalimat (1) dan (1.a; 1.b; 1.c), (2) dan (2.a), serta (3) dan (3.a) berikut ini.

(1) Anak itu menggambari lengannya dengan gambar naga.

(1.a) Anak itu menggambar naga.

(1.b) *Anak itu menggambari lengannya.

(1.c) Anak itu menggambar naga di lengannya

(2) Ia suka mencubiti lengan temannya.

(2.a) Ia suka mencubit lengan temannya.

(3) Pada menjelang usia remaja, ia sudah suka memerahi bibirnya.

(3.a) *Pada menjelang usia remaja, ia sudah suka memerah bibirnya.

Bukti bahwa akhiran /-i/ pada kalimat (1) bermakna 'lokatif' dan bukan 'objektif dapat dilihat pada perbandingan antara kalimat (1.a), (1.b) dan (1.c). Kalimat (1.b) adalah kalimat yang tidak berterima; setidaktidaknya secara semantis bukan merupakan kalimat yang lengkap. Ketidakberterimaan kalimat (1.b) ditandai oleh peran 'lokatif' yang dimiliki oleh bentuk lengannya yang menduduki fungsi objek. Karena fungsi objek diisi oleh bentuk lingual yang berperan 'lokatif', struktur semantis kalimat itu masih menghendaki hadirnya bentuk lingual lain yang berperan 'pelengkap' yaitu 'wujud gambar' itu sendiri. Hal itu berbeda dengan kalimat (1.a) dan (1.c). Kalimat (1.a) berterima karena hadimya bentuk naga pada fungsi objek yang berperan 'pelengkap' secara semantis telah melengkapi kalimat itu, walaupun sesungguhnya demi kelengkapan yang sempurna masih pula menuntut hadimya 'lokasi' pembuatan gambar itu, yaitu seperti yang ditandai oleh frasa di lengannya pada kalimat (1.c). Perbandingan antara kalimat (2) dan (2.a) dapat membedakan antara tindakan yang dilakukan berulangulang dan tindakan yang tidak dilakukan secara berulang-ulang. Kalimat (3) dan (3.a) dapat menunjukkan bahwa hadimya akhiran /-i/ bersifat wajib, yakni agar satuan lingual bibirnya dapat menduduki fungsi objek dan berperan sebagai 'sasaran' karena ketidakhadirannya pada kalimat (3.a) membuatnya tidak berterima. 
Sehubungan dengan uraian di atas, dapatkah akhiran $/-\mathrm{i} /$ itu dipandang sebagai sebuah morf saja? Kemudian, apakah morf itu dapat ditafsirkan sebagai morf yang memiliki beebrapa makna? Akhimya, dapatkan disimpulkan bahwa morf itu merupakan morf amalgam?

Untuk menjawab pertanyaan-pertanyaan itu pembicaraan harus dikembalikan kepada pengertian morf dan morfem di atas. Morf adalah perwujudan morfem dan morfem adalah unit abstrak yang memiliki bentuk dan arti minimal. Penekanan pada pernyataan arti minimal tampaknya sangat penting. Berdasarkan penekanan itu dapat dikaji ulang apakah akhiran /-i/ pada kata-kata di atas memiliki satu makna atau beberapa makna. Artinya, morf apakah /-i/ pada kata menggambari memiliki satu makna saja atau memiliki dua makna atau lebih. Jika dilihat ulang, morf /-i/ memang hanya memiliki makna 'lokatif' dan tidak memiliki makna yang lain. Demikian pula morf /-i/ pada kata mencubiti dan memerahi. Dengan demikian, sesuai dengan pengertian morfem sebagai unit makna terkecil yang berkorelasi dengan unit bentuk terkecil, berarti morf-morf /-i/ itu masing-masing merupakan perwujudan sebuah morfem saja. Oleh karena itu, morf-morf itu tidak atau bukan morf-morf yang bersifat amalgam.

Di samping fenomena di atas, bahasa Indonesia juga memiliki morf pen- yang di samping merealisasikan morfem $\{\mathrm{pe}(\mathrm{N})-\}$ juga merealisasikan makna \{tindakan\}, \{aktif\}, dan \{persona\} seperti pada kata pembeli, pembunuh, penjual, dan masih banyak lagi. Lebih jelas lagi, bila diperbandingkan antara pesuruh dan penyuruh, petatar dan penatar. $\mathrm{Di}$ dalam kata pesuruh dan petatar terdapat morf /pe-/ yang di samping mewujudkan morfem \{pe-\}, juga merealisasikan makna \{persona\} dan \{pasif\}, sedangkan morf /peñ-/ di dalam kata penyuruh dan morf /pen-/ di dalam kata penatar, di samping merealisasikan morfem $\{p e(N)-\}$ juga merealisasikan makna \{persona\}, \{tindakan\}, dan \{aktif\}. Dengan demikian dapat diketahui bahwa walaupun keduanya sama-sama merealisasikan makna \{persona\}, morf /pe-/ dan morf /peñ-/ atau /pen-/ memiliki muatan makna yang berbeda. Makna \{tindakan\} yang diwujudkan oleh morf /peñ-/ dan /pen-/ tidak dimiliki oleh morf /pe-/. Di samping itu, keduanya menampakkan perbedaan dalam hal makna \{aktif\} dan \{pasif\}.

Berbeda dengan kasus yang dialami oleh morf /-i/ pada kata menggambari, mencubiti, dan memerahi yang masing-masing adalah morf yang mewujudkan sebuah morfem, morf/peñ-/ dan /pen-/ yang terdapat pada 
kata penyuruh dan penatar tersebut masing-masing adalah morf yang mewujudkan dua morfem atau lebih. Dengan demikian, morf /peñ-/ atau /pen-/ tersebut dapat dipandang sebagai morf amalgam. Demikian pula morf /pe/ yang merupakan kontras dari kedua morf itu, juga termasuk morf amalgam karena morf itu mewujudkan makna 'persona' dan 'pasif' atau 'yang di'.

Lebih lanjut, di dalam bahasa Indonesia juga dikenal adanya bentuk paduan atau blend, seperti apa yang ditunjukkan oleh Bauer yang telah dikemukakan di atas. Bentuk rudal adalah paduan dari bentuk/ru-/ yang diambil dari leksem peluru dan bentuk/-dal/ yang diambil dari leksem kendali. Makna yang dimiliki oleh leksem peluru tidak dapat lagi dikenali pada /ru-/ dan makna yang dimiliki oleh leksem kendali tidak dapat lagi dikenali pada /-dal/, yang masing-masing digunakan dalam bentuk paduan rudal. Identitas rudal sebagai leksem lebih dapat dipahami oleh adanya bentuk-bentuk kata merudal, dirudal, merudali, dirudali, perudalan, rudalrudal, rudal-merudal, rudal jarak sedang, rudal anti rudal, dan sebagainya. Morf rudal tersebut dapat dianggap merealisasikan dua morfem, yaitu \{peluru\} dan \{kendali\}. Dengan demikian morf-morf sejenis rudal tersebut termasuk morf amalgam, misalnya seperti juklak, juknis, rantap, rantus, sendratasik, dan sejenisnya.

Berdasarkan uraian di atas dapat disimpulkan bahwa bentuk-bentuk amalgam dalam bahasa Indonesia dapat berupa afiks dan leksem. Sebagai bentuk amalgam, afiks-afiks itu memiliki status morfemis ganda, yaitu ciri bentuk sebuah morf afiks yang mewakili atau memiliki dua status morfem atau lebih. Demikian pula bentuk-bentuk amalgam yang berupa leksem yang hanya menampakkan ciri bentuk sebuah morf walaupun memiliki dua status morfem atau lebih.

\section{Morf Amalgam dan Gejala Homonimi}

Dalam bahasa Indonesia terdapat sejumlah satuan lingual yang memiliki ciri bentuk yang sama namun memiliki ciri makna yang berbeda. Bentuk bisa pada binatang berbisa dan bisa binatang secara semantis berbeda dengan bentuk bisa pada bisa bernyanyi. Bentuk yang pertama memiliki makna 'racun' sedangkan bentuk kedua berarti 'dapat' atau 'mampu', 'sanggup'. Bentuk beruang pada tidak beruang secara semantis berbeda dengan bentuk beruang pada induk beruang. Yang pertama berarti 'memiliki 
uang' dan yang kedua berarti 'binatang'. Gejala semacam ini biasa disebut gejala homonimi, yaitu dua satuan lingual yang memiliki ciri bentuk yang sama namun memiliki ciri makna yang berbeda.

Keberadaan morf amalgam dalam suatu bahasa, misalnya dalam bahasa Indonesia, memiliki gejala yang hampir sama dengan gejala homonimi. Hal itu dapat dipahami karena baik gejala morf amalgam dan gejala homonimi sama-sama berkenaan dengan adanya kesamaan bentuk dan sama-sama berkenaan dengan adanya kemungkinan arti lebih dari satu. Namun jika dicermati, kedua gejala itu memang berbeda. Ciri semantis atau ciri makna yang terdapat dalam gejala homonimi dapat dikenali berdasarkan konteks atau lingkungan yang menyertainya sedangkan ciri makna yang dimiliki oleh morf amalgam bergantung pada ciri bentuk morf itu sendiri, walaupun tetap dalam hubungannya dengan morf lain dalam suatu konstruksi kata. Secara leksikal makna kata bisa tidak dapat ditentukan sebelum kata itu berada di dalam konstruksi sintaktis yang secara hierarkhis di atasnya, misalnya di dalam konstruksi frasa atau klausa. Hal itu telah ditunjukkan oleh contoh di atas. Berbeda halnya dengan morf amalgam, ciri makna \{persona\}, \{aktif\}, dan \{tindakan\} benar-benar dimiliki oleh morf /pen-/ pada konstruksi kata yang sama, misalnya penyuruh dan penatar, serta banyak lagi yang lain. Di dalam kata penyuruh terdapat morf /peñ-/ yang sekaligus memiliki makna 'orang', 'melakukan tindakan', 'aktif', dan 'transitif. Setidak-tidaknya ciri makna itu dapat dikelompokkan menjadi dua, yaitu 'orang' atau 'persona' dan 'tindakan', yang di dalam makna 'tindakan' itu sendiri terdapat subfitur semantis 'aktif' dan 'transitif'. Demikian pula morf /pen-/ pada kata penatar. Kondisi seperti itu dapat dikontraskan dengan morf /pe-/ pada kata pesuruh dan petatar yang tidak memiliki ciri semantis 'tindakan' karena morf /pe-/yang berciri makna 'persona' itu memiliki ciri makna 'pasif. Tentu saja morf apa pun yang berciri 'pasif' tidak akan memiliki ciri 'tindakan' karena ciri makna 'tindakan' atau 'action' hanya terdapat bersama-sama dengan ciri 'aktif'. Dalam hal ini fitur semantis 'pasif' semestinya ditafsirkan sebagai 'tidak ada tindakan'.

Lebih jauh lagi, di dalam kalimat Ali menyuruh Topan terdapat makna 'tindakan' sementara di dalam kalimat Topan disuruh Ali, makna 'tindakan' itu tidak ada. Di dalam kalimat pertama $A l i$ adalah 'pelaku' atau 'aktor' yang melakukan 'tindakan' suruh, sementara di dalam kalimat pasif, yaitu kalimat kedua, oleh adanya pengedepanan peran 'pengalam' atau 
'penderita', makna 'tindakan' itu menjadi tidak tampak. Hal itu sesuai dengan sifat kalimat aktif yang memiliki penonjolan 'pelaku' dan sifat kalimat pasif yang memiliki penonjolan 'pengalam' atau 'penderita'.

Kembali pada permasalahan semula, berdasarkan kontras antara morf /peñ-/ dan /pe-/ atau antara /pen-/ dan /pe-/ dapat diketahui bahwa terdapat morf yang memiliki fitur atau ciri semantis lebih dari satu yang secara bersama-sama dimiliki oleh morf yang bersangkutan dalam satu konstruksi kata yang sama, yaitu 'persona' dan 'tindakan' pada morf /peñ-/ atau /pen- $/$ serta 'persona' dan 'tidak ada tindakan' atau 'pasif' pada morf /pe-/. Hal itu jauh berbeda dengan gejala yang terdapat pada bentuk-bentuk homonimi seperti telah dikemukakan di atas.

\section{E. Morf Amalgam dan Gejala Polisemi}

Satu hal lagi yang perlu dikemukakan di sini sehubungan dengan gejala morf amalgam dalam bahasa Indonesia ialah gejala polisemi. Di dalam bahasa-bahasa sudah sangat lazim dikenal adanya gejala itu. Seperti sudah dikemukakan di atas, lazimnya, gejala kepolisemian itu berkenaan dengan tataran kata atau leksikal, yaitu suatu kata (baca: bentuk kata) yang berkorelasi dengan sejumlah (atau lebih dari satu) ciri makna. Kepolisemian yang berkenaan dengan tataran morfem tampaknya belum begitu lazim dibicarakan dalam buku-buku morfologi atau di dalam buku-buku semantik yang ada; setidak-tidaknya dalam publikasi linguistik Indonesia. Permasalahannya, apakah gejala morf amalgam itu dapat disatujeniskan dengan gejala kepolisemian? Jelasnya, apakah morf-morf amalgam itu termasuk bentuk-bentuk yang bersifat polisemi?

Kridalaksana (1993:175) menyatakan bahwa polisemi (polysemy, multiple meaning) adalah pemakaian bentuk bahasa seperti kata, frase, dan sebagainya dengan makna yang berbeda-beda; misalnya sumber yang dapat berarti 'sumur', 'asal', atau 'tempat sesuatu yang banyak'. Demikian pula seperti kambing hitam yang dapat berarti 'kambing yang hitam' atau 'orang yang dipersalahkan'. Dengan bersandar pada pendapat Kridalaksana tersebut dapat dipahami bahwa posilemi itu suatu gejala pemakaian satuan lingual tertentu dengan makna yang berbeda-beda sesuai dengan konteks yang pembicaraan. Kata sumber dapat bermakna 'sumur' dalam kalimat Simbok sedang mengambil air ke sumber. Kata yang sama dapat bermakna 'asal' dalam kalimat Sumber pil-pil memabukkan itu juga harus ditemukan. 
Pemakaian kata dengan makna berbeda-beda itu juga terdapat pada kalimat Bunga desa itu harus menanggung bunga bank yang tinggi demi kelestarian hidup bunga langkanya. Kata bunga dalam kalimat itu bermakna 'gadis', 'jasa', dan 'kembang'.

Menilik pengertian polisemi seperti telah diuraikan di atas, dapat dikemukakan bahwa keberadaan morf amalgam berbeda dengan keberadaan satuan lingual apa pun yang berpolisemi. Polisemi sebagai pemakaian bentuk-bentuk kebahasaan dengan berbagai makna berkenaan dengan pemakaian bentuk kebahasaan dengan makna yang bersifat metaforis. Relasi makna yang terjadi dalam polisemi bersifat ekstralingual. Artinya, berbagai makna yang terjadi dalam gejala polisemi disebabkan oleh adanya peralihan referen secara luar bahasa. Kata sumber yang awalnya memiliki referen 'tempat keluarnya air' mengalami peralihan kepada 'asal sesuatu' atau 'tempat sesuatu yang banyak'. Demikian pula kata bunga yang awalnya memiliki referen 'kembang' mengalami peralihan pada 'gadis' atau 'uang jasa'. Hal itu berbeda dengan morf amalgam. Relasi makna yang terjadi dalam keamalgaman bersifat intralingual atau bersifat gramatikal. Makna 'persona', 'tindakan', 'aktif' yang diwujudkan oleh morf /pen-/ adalah akibat relasi morfologis antara morf tersebut dan bentuk dasar yang dilekatinya serta relasi kata derivasi yang dibentuknya dengan kata-kata lain dalam konstruksi sintaktis.

\section{F. Simpulan}

Istilah morf dan morfem sudah banyak disinggung dalam buku-buku morfologi. Hubungan antara morf dan morfem sama dengan hubungan antara wujud dan fungsi; antara bentuk dan arti; antara wujud dan yang diwujudkan. Bila morfem dibatasi sebagai unit kebahasaan yang bersifat abstrak; atau unit gramatikal terkecil; atau unit bermakna terkecil, morf dibatasi sebagai wujud unit dari gramatikal atau unit bermakna terkecil yang bersifat abstrak itu. Singkatnya, morf adalah wujud morfem.

Relasi antara morf dan morfem sebagai wujud dan yang diwujudkan menampakkan tiga kemungkinan: (1) satu morf merealisasikan satu morfem, (2) dua morf atau lebih merealisasikan satu morfem, dan (3) satu morf merealisasikan dua morfem atau lebih. Morf yang merealisasikan lebih dari satu morfem disebut morf amalgam. 
Morf amalgam dalam bahasa Indonesia dapat berupa afiks atau leksem. Morf amalgam yang berupa afiks dapat ditunjukkan oleh morf/peñ-/ atau /pen-/ pada kata penyuruh dan penatar. Morf /peñ-/ atau /pen-/ pada kedua kata itu merealisasikan makna 'persona', tindakan', dan 'aktif. Berbeda dengan morf /pe-/ yang terdapat pada kata pesuruh dan petatar yang merealisasikan makna 'persona' dan 'pasif' atau 'tidak ada tindakan'. Berdasarkan perbandingan keduanya, dapat diketahui bahwa hadir atau tidak hadimya makna 'tindakan' dan atau 'aktif' dimarkahi oleh hadir atau tidak hadirnya nasal $/ \tilde{\mathbf{n}} /$ atau $/ \mathrm{n} /$. Dengan demikian, dapat dikatakan bahwa nasal $/ \tilde{\mathbf{n}} /$ atau $/ \mathrm{n} /$ merupakan pemarkah ciri semantis 'tindakan' atau 'aktif'. Terlepas dari perbedaan keduanya, morf /peñ-/, /pen-/, dan /pe-/ adalah morf-morf amalgam karena masing-masing merealisasikan dua morfem, yaitu di samping \{persona\} juga \{tindakan\}, \{aktif\}, atau \{pasif\}.

Morf amalgam yang berupa leksem ditunjukkan oleh bentuk akronim, misalnya, rudal, radar, juklak, juknis, rantap, rantus, dan banyak lagi lainnya. Bentuk rudal sebagai leksem yang memiliki dua makna leksekal, yaitu 'peluru' dan 'kendali' memang berasal dari gabungan leksem peluru dan kendali. Namun demikian, makna 'peluru' tidak dapat lagi diidentifikasi melalui bentuk /ru-/ dan makna 'kendali' tidak lagi dapat dikenali melalui bentuk/-dal/. Identitas rudal sebagai leksem lebih dapat dipahàmi oleh adanya bentuk-bentuk kata merudal, dirudal, merudali, dirudali, perudalan, rudal-rudal, rudal-merudal, rudal jarak sedang, rudal anti rudal, dan sebagainya. Morf rudal tersebut dapat dianggap merealisasikan dua morfem, yaitu \{peluru\} dan \{kendali\}. Dengan demikian morf-morf sejenis rudal tersebut termasuk morf amalgam.

Gejala yang terjadi pada morf amalgam berbeda dengan gejala homonimi dan polisemi. Homonimi berkenaan dengan dua bentuk (pada umumnya kata) yang sama yang berhubungan dengan dua arti yang berbeda, sedangkan polisemi berkenaan dengan satuan-satuan lingual yang dipakai dengan arti yang berbeda-beda. Dua kata yang sama atau homonim tetap merupakan dua kata. Beberapa makna yang dimiliki oleh suatu satuan lingual, atau kepolisemian, di antaranya disebabkan oleh pemakaian bahasa secara metaforis. Di dalam pemakaian pun, hubungan bentuk dan arti tetap bersifat satu lawan satu. Dengan demikian dapat ditegaskan bahwa gejala yang dialami oleh morf amalgam berbeda dengan gejala yang teriadi dalam bentuk-bentuk homonimi atau polisemi. 


\section{DAFTAR PUSTAKA}

Bauer, Laurie. 1988. Introducing Linguistic Morphology. Edinburgh: Edinburgh University Press

Chafe, Wallace L. 1970. Meaning and The Structure of Language. Chicago: The University of Chicago

Kridalaksana, Harimurti. 1984. Kamus Linguistik. Jakarta: Penerbit PT Gramedia.

1989. Pembentukan Kata dalam Bahasa Indonesia. Jakarta: Penerbit PT Gramedia.

1994. Kelas Kata dalam Bahasa Indonesia. Jakarta: Penerbit PT Gramedia Pustaka Utama.

Matthews, P.H. 1974. Morphology, an introduction to the theory of word structure. Cambridge: University Press.

Ramlan. 1987. Ilmu Bahasa Indonesia: Morfologi Suatu Tinjauan Deskriptif. Yogyakarta: C.V. Karyono.

Robin, R.H. 1992. Linguistik Umum: Sebuah Pengantar. Terjemahan Soenarjati Djajanegara. Seri ILDEP. Yogyakarta: Kanisius.

Verhaar, J.W.M. 1977. Pengantar Linguistik Umum. Yogyakarta: Gadjah Mada University Press.

. 1995. Azas-azas Linguistik Umum. Yogyakarta: Gadjah Mada University Press. 